\title{
FAKTOR-FAKTOR YANG BERPENGARUH TERHADAP MOTIVASI BELAJAR MAHASISWA DI STMIK STIKOM BALI
}

\author{
I Gusti Ngurah Satria Wijaya \\ Program Studi Sistem Informasi STMIK Stikom Bali \\ ngurah_satria@stikom-bali.ac.id
}

\begin{abstract}
ABSTRAK
Dalam kegiatan belajar mengajar peranan motivasi sangat diperlukan. Rendahnya motivasi belajar mahasiswa seringkali diduga menjadi penyebab rendahnya kualitas lulusan sebuah perguruan tinggi. Hal ini menyebabkan di beberapa perguruan tinggi swasta, faktor motivasi belajar mendapatkan perhatian khusus. Berdasarkan latar belakang diatas, penulis melakukan penelitian yang bertujuan untuk meneliti faktor-faktor yang berpengaruh terhadap motivasi belajar mahasiswa di STIMIK Stikom Bali. Data yang digunakan dalam penelitian ini adalah data primer yang berasal dari pengisian kuisioner dari mahasiswa STIMIK Stikom Bali sebanyak 50 sampel. Teknik analisis yang digunakan dalam penelitian ini adalah regresi linier berganda dimana variabel independennya adalah faktor intrinsik (dalam diri mahasiswa) dan faktor ekstrinsik (kualitas dosen, orang tua, materi kuliah, metode perkuliahan, perpustakaan, ruang kuliah dan laboratorium). Hasil dari penelitian ini adalah faktor intrinsik, kualitas dosen, metode perkuliahan, materi kuliah, orang tua, ruang perkulihan/laboratorium, dan perpustakaan secara simultan mempunyai pengaruh yang signifikan terhadap motivasi belajar mahasiswa. Serta secara parsial, faktor intrinsik, kualitas dosen, metode perkuliahan, materi kuliah, orang tua, ruang kuliah/laboratorium, dan perpustakaan menunjukkan hubungan yang positif terhadap variabel dependen yaitu motivasi belajar mahasiswa. Hasil penelitian ini pada nantinya dapat memberikan hasil evaluasi bagi manajemen pengelola STMIK STIKOM Bali tentang faktor-faktor yang berpengaruh terhadap motivasi belajar mahasiswa.
\end{abstract}

Kata kunci : motivasi belajar

\section{ABSTRACT}

In teaching and learning activities the role of motivation is very necessary. The low motivation of student learning is often thought to be the cause of the low quality of graduates of a college. This causes in some private universities, learning motivation factors get special attention. Based on the above background, the authors conducted a study that aims to examine the factors that affect student learning motivation in STIMIK Stikom Bali. The data used in this study is the primary data derived from the filling questionnaire from STIMIK STIKOM Bali students as many as 50 samples. The analysis technique used in this research is multiple linear regression where the independent variable is intrinsic factor (in student) and extrinsic factor (quality of lecturer, parent, lecture material, lecture method, library, lecture room and laboratory). The result of this research is intrinsic factor, lecturer quality, lecture method, lecture material, parent, rehabilitation / laboratory space, and library simultaneously have a significant influence on student learning motivation. And partially, intrinsic factor, lecturer quality, lecture method, lecture material, parent, lecture / laboratory space, and library show a positive relationship to the dependent variable that is student's learning motivation. The results of this study in the future can provide evaluation results for the management of STMIK STIKOM Bali management about factors that affect student learning motivation

Keywords : learning motivation 


\section{PENDAHULUAN}

STMIK Stikom Bali sebagai salah satu penyelenggara pendidikan tinggi di Bali mempunyai komitmen untuk melaksanakan pendidikan sebaik mungkin, secara khusus bertujuan untuk menghasilkan lulusan yang berkompeten dan siap bersaing dalam dunia kerja serta mampu menciptakan lapangan kerja sendiri dalam persaingan era globalisasi ini. Tersirat dalam visi kampus STIKOM Bali yaitu menjadi perguruan tinggi unggulan dan berkualitas global di bidang ICT (Informasi Communication Technology) tahun 2020 dan salah satu misi kampus yaitu menyelenggarakan Pendidikan Tinggi secara profesional dan berkualitas. Berbagai fasilitas pendidikan sudah tersedia di Stikom Bali seperti ruang kelas yang memadai, perpustakaan, dan sarana fisik lainnya yang berbasis teknologi. Pengajar atau dosen yang berkompeten siap untuk membimbing mahasiswa dalam proses belajar, dan sistem pengajaran maupun sistem administrasi yang berbasis IT sudah tersedia untuk mendukung kegiatan mahasiswa.

Salah satu faktor yang mempengaruhi prestasi belajar adalah faktor dari dalam diri seseorang yang meliputi keadaan fisiologis dan psikologis, faktor fisiologis meliputi keadaan fisik seseorang secara umum, kondisi panca indra, sedangkan faktor psikologis meliputi minat, bakat, motivasi dan kemampuan kognitif. Hal ini berarti berarti bahwa prestasi belajar yang rendah dapat disebabkan oleh motivasi belajar yang rendah. Keberhasilan peserta didik (mahasiswa) dalam aktivitas pendidikan tidak akan lepas dari dorongan (motivasi) yang ditanamkan pada mahasiswa tersebut.
Motivasi adalah sebagai suatu daya (dorongan) pada seseorang yang menyebabkan seseorang melakukan perbuatan tertentu. Menurut Nurhidayah (2014), motivasi belajar seseorang dipengaruhi oleh dua faktor yaitu faktor ekstrinsik meliputi lingkungan (alam dan sosial), perhatian orang tua, kurikulum, pengajar, sarana prasarana, fasilitas, dan administrasi, sedang faktor yang kedua yaitu faktor intrinsik yang meliputi fisiologis (kondisi fisik) dan psikologi (sikap, bakat, minat, kecerdasan, dan kemampuan koqnitif).

Dalam kegiatan belajar mengajar peranan motivasi sangat diperlukan. Rendahnya motivasi belajar mahasiswa seringkali diduga menjadi penyebab rendahnya kualitas lulusan sebuah perguruan tinggi. Hal ini menyebabkan di beberapa perguruan tinggi swasta, faktor motivasi belajar mendapatkan perhatian khusus. Faktor ini menimbulkan persoalan yang dilematis. Sebenarnya tidak mungkin seorang mahasiswa dapat menguasai bahan pembelajaran dengan baik apabila motivasi belajarnya rendah namun jika diluluskan, hal ini akan berdampak kepada mahasiswa.

Untuk penelitian-penelitian sebelumnya tentang faktor-faktor yang mempengaruhi motivasi belajar mahasiswa masih menunjukkan hasil yang berbedabeda. Upoyo dan Sumarwati (2011) dalam penelitiannya memperoleh hasil yaitu faktor yang berpengaruh secara signifikan terhadap tingkat motivasi mahasiswa adalah dorongan internal, faktor beban tugas dan lingkungan rumah sakit. Faktor lain seperti lama pelaksanaan, metode, peran pembimbing klinik, dan peran pembimbing akademik belum memberikan pengaruh yang signifikan terhadap 
peningkatan motivasi mahasiswa profesi. Berbeda dengan hasil penelitian yang dibuat oleh Martono dan Sulistiowati (2012). Martono dan Sulistiowati (2012) memperoleh hasil yaitu faktor intrinsik (diri mahasiswa) dan ektrinsik (perpustakaan, laboratorium, kualitas dosen, materi kuliah, metode perkuliahan dan ruang perkuliahan) memberikan kontribusi yang positif untuk meningkatkan motivasi belajar mahasiswa STIKOM Surabaya.

Berdasarkan latar belakang diatas dan terjadinya gap atau perbedaan hasil pada penelitian-penelitian sebelumnya, penulis melakukan penelitian yang bertujuan untuk meneliti faktor-faktor yang mempengaruhi motivasi belajar mahasiswa di STIMIK Stikom Bali Untuk variabel-variabel penelitian yang digunakan dalam penelitian faktor-faktor yang mempengaruhi motivasi belajar mahasiswa STIMIK Stikom Bali adalah faktor intrinsik (dalam diri mahasiswa) dan faktor ekstrinsik (kualitas dosen, orang tua, materi kuliah, metode perkuliahan, perpustakaan, dan ruang kuliah/laboratorium) dari mahasiswa.

\section{METODE PENELITIAN}

Teknik pengumpulan data primer yang dilakukan dalam penelitian ini adalah dengan penyebaran kuisioner. Kuisioner tersebut disebarkan pada responden mahasiswa STIKOM Bali, dimana untuk penentuan responden dilakukan dengan teknik sampling purposive. Teknik sampling ini merupakan penentuan sampel dengan pertimbangan tertentu. Jumlah sampel mahasiswa yang digunakan melalui penyebaran kuisionernya adalah sebanyak 50 sampel mahasiswa.

Pengujian hipotesis untuk faktorfaktor yang mempengaruhi motivasi belajar mahasiswa menggunakan analisis regresi linier berganda (Multiple Regression) dengan memakai alat bantu aplikasi SPSS 16.0 (Statistical Package for Social Science). Pengujian dengan analisis regresi linier berganda dilakukan untuk menguji pengaruh lebih dari satu variabel independen terhadap variabel dependen. (Ghozali, 2011).

\section{HASIL \& PEMBAHASAN}

\section{A. Hasil}

\section{Deskripsi Responden dan Statistik Deskriptif Penelitian}

Berdasarkan jenis kelamin, responden pria terdiri dari 66 responden $\quad(73,3 \%)$, sedangkan responden wanita terdiri dari 24 responden $(26,7 \%)$. Berdasarkan usia, responden yang berusia paling muda adalah 18 tahun, sedangkan responden yang berusia paling tua adalah 37 tahun. Mayoritas responden berusia diantara 18 tahun hingga 23 tahun. Berdasarkan sumber dana perkuliahan, sumber dana perkuliahan yang berasal dari orang tua sebanyak $70 \%$. Sedangkan sumber dana perkuliahan yang berasal dari diri sendiri sebanyak $30 \%$. Berdasarkan pelatihan yang pernah diikuti, sebanyak $60 \%$ responden pernah mengikuti pelatihan, sisanya sebanyak $40 \%$ responden tidak pernah mengikuti pelatihan. 
Tabel 5.1. Statistik Deskriptif Variabel Penelitian

\begin{tabular}{lrccc}
\hline \multirow{2}{*}{ Variabel } & \multicolumn{2}{c}{ Kisaran } & \multicolumn{2}{c}{ Rata-rata } \\
\cline { 2 - 5 } & Teoritis & Empiris & Teoritis & Empiris \\
\hline Faktor Intrinsik & $4-20$ & $8-20$ & 12 & 14 \\
\hline Kualitas Dosen & $4-20$ & $8-20$ & 12 & 14 \\
\hline Metode Perkuliahan & $4-20$ & $8-20$ & 12 & 14 \\
\hline Materi Kuliah & $4-20$ & $12-20$ & 12 & 16 \\
\hline Orang Tua & $3-15$ & $6-15$ & 9 & 14 \\
\hline $\begin{array}{l}\text { Ruang } \\
\text { Perkuliahan/Laboratorium }\end{array}$ & $5-25$ & $10-25$ & 15 & 17,5 \\
\hline Perpustakaan & $5-25$ & $10-25$ & 15 & 17,5 \\
\hline Motivasi Belajar & $7-35$ & $14-35$ & 21 & 32 \\
\hline
\end{tabular}

Berdasarkan tabel 1, dapat dilihat bahwa pada variabel faktor intrinsik, kualitas dosen, metode perkuliahan, materi kuliah, orang tua, ruang perkulihan/laboratorium, perpustakaan, dan motivasi belajar terdapat responden yang mempunyai nilai jawaban pada tingkat tertinggi namun tidak ada responden yang mempunyai nilai jawaban yang terendah. Berdasarkan tabel 1 juga dapat dilihat bahwa jawaban yang diberikan oleh responden pada variabel faktor intrinsik, kualitas dosen, metode perkuliahan, materi kuliah, orang tua, ruang perkulihan/laboratorium, dan perpustakaan, menunjukkan jumlah skor jawaban yang cenderung tinggi. Hal ini terlihat dari rata-rata jawaban responden pada semua variabel yang lebih tinggi dari rata-rata teoritisnya. Hal ini menunjukkan adanya penilaian dari responden bahwa faktor intrinsik, kualitas dosen, metode perkuliahan, materi kuliah, orang tua, ruang perkulihan/laboratorium, dan perpustakaan sudah cukup baik.

\section{Uji Kualitas Data}

Hasil uji validitas menunjukkan bahwa keseluruhan indikator variabel yang digunakan dalam penelitian ini memiliki nilai Pearson Correlation yang lebih tinggi dari 0,5. Oleh karena itu dapat dikatakan bahwa semua indikator pengukur variabel tersebut adalah valid.

Hasil uji reliabilitas menunjukkan bahwa keseluruhan variabel memiliki nilai Cronbach's Alpha yang lebih tinggi dari 0,6. Oleh karena itu dapat dikatakan bahwa keseluruhan pengukur variabel yang digunakan dalam penelitian ini adalah reliabel.

\section{Uji Asumsi Klasik}

Selanjutnya hasil analisis dengan uji asumsi klasik dapat diuraikan pada tabel berikut ini. 
Tabel 5.2. Normalitas

\begin{tabular}{llr}
\hline & & \multicolumn{1}{c}{$\begin{array}{c}\text { Unstandardized } \\
\text { Residual }\end{array}$} \\
\hline $\mathrm{N}$ & \multicolumn{1}{c}{ Mean } & 90 \\
\cline { 2 - 3 } & Std. Deviation & .0000000 \\
\hline Normal Parameters ${ }^{\mathrm{a}}$ & Absolute & .33319850 \\
\cline { 2 - 3 } & Positive & .102 \\
\cline { 2 - 3 } & Negative & .058 \\
\hline Kolmogorov-Smirnov Z & &. .102 \\
\hline Asymp. Sig. (2-tailed) & & .964 \\
\hline
\end{tabular}

Hasil uji normalitas menunjukkan bahwa nilai Kolmogorov-Smirnov adalah sebesar 0,964 dan tingkat signifikansi pada 0,311 . Tingkat signifikansi ini lebih besar dari dari tingkat signifikansi penelitian yaitu 0,05 . Oleh karena itu dapat disimpulkan bahwa data residual terdistribusi secara normal.

Tabel 5.3. Uji Multikolonieritas

\begin{tabular}{llll}
\hline & \multicolumn{1}{c}{ Model } & \multicolumn{2}{c}{ Collinearity Statistics } \\
\cline { 2 - 4 } & Tolerance & VIF \\
\hline 1 & (Constant) & & \\
\cline { 2 - 4 } & Faktor Intrinsik (Diri Sendiri) & .468 & 2.136 \\
\cline { 2 - 4 } Kualitas Dosen & .434 & 2.303 \\
\cline { 2 - 4 } Metode Perkuliahan & .483 & 2.072 \\
\cline { 2 - 4 } Materi Kuliah & .482 & 2.075 \\
\cline { 2 - 4 } & Orang Tua & .719 & 1.390 \\
\cline { 2 - 4 } Ruang Kuliah / Laboratorium & .617 & 1.620 \\
\cline { 2 - 4 } & Perpustakaan & .694 & 1.440 \\
\hline
\end{tabular}

Hasil uji multikolonieritas menunjukkan bahwa keseluruhan variabel memiliki nilai tolerance diatas
0,1 dan memiliki nilai VIF dibawah 10 . Oleh karena itu dapat dikatakan bahwa tidak terjadi multikolinearitas antar variabel independen dalam model regresi. 


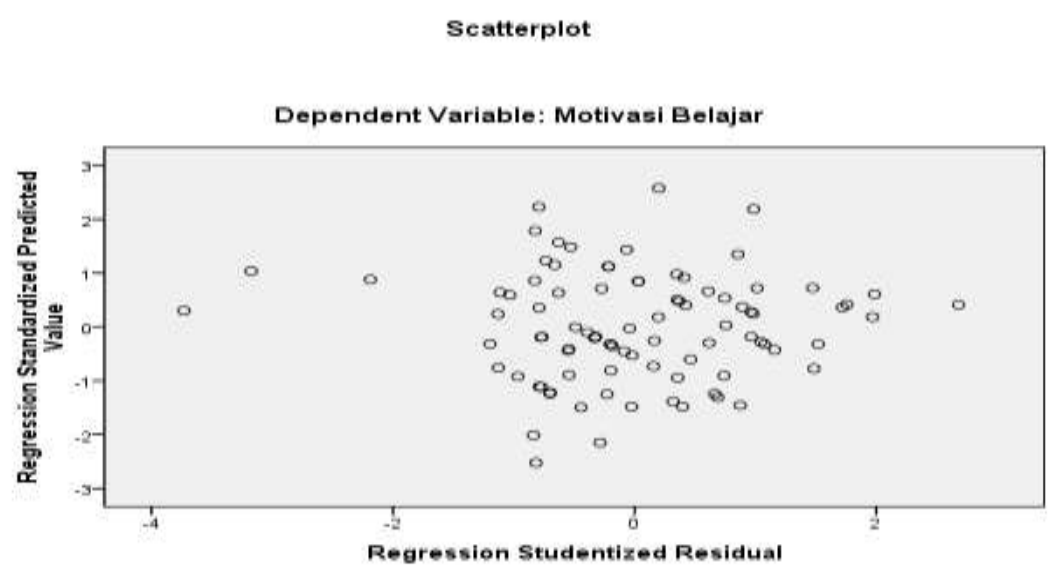

Gambar 5.1. Scatterplot

Hasil uji heterokedastisitas bersifat homoskedastisitas

menunjukkan bahwa dari hasil output gambar 5.1 scatterplot, didapat titik menyebar di bawah serta di atas sumbu Y, dan tidak mempunyai pola yang teratur. Maka dapat disimpulakan variabel bebas di

\section{Uji Regresi Linier Berganda}

Adapun analisis regresi linier berganda dapat ditampilkan sebagai berikut: atas tidak terjadi heteroskedastisitas atau

Tabel 5.4. Uji Regresi Linier Berganda

\begin{tabular}{lrrrrr}
\hline Model & R & R Square & $\begin{array}{c}\text { Adjusted R } \\
\text { Square }\end{array}$ & F & \multicolumn{2}{l}{ Sig. } \\
\hline 1 & $.668^{\mathrm{a}}$ & .446 & .399 & 9.428 & .000 \\
\hline
\end{tabular}

Berdasarkan tabel 5.4, dapat dilihat bahwa model regresi ini memiliki nilai Adjusted $\mathrm{R}^{2}$ sebesar 0,399. Hal ini berarti variabilitas variabel dependen yang dapat dijelaskan oleh variabilitas variabel independen adalah sebesar 39,9\%. Sedangkan sisanya sebesar $60,1 \%$ dijelaskan oleh variabel lain yang tidak dimasukkan dalam model regresi.

Berdasarkan tabel 5.4, dapat dilihat bahwa model regresi ini memiliki nilai $\mathrm{F}$ sebesar 9,428 dengan tingkat signifikansi
0,000. Karena tingkat signifikansi tersebut lebih kecil dari tingkat signifikansi penelitian $(0,05)$, maka dapat disimpulkan bahwa pada tingkat signifikansi 5\%, variabel faktor intrinsik, kualitas dosen, metode perkuliahan, materi kuliah, orang tua, ruang perkulihan/laboratorium, dan perpustakaan secara simultan mempunyai pengaruh yang signifikan terhadap motivasi belajar mahasiswa. 
Tabel 5.4. Uji Regresi Linier Berganda

\begin{tabular}{|c|c|c|c|c|}
\hline \multirow{2}{*}{\multicolumn{2}{|c|}{ Model }} & \multirow{2}{*}{$\begin{array}{c}\text { Standardized } \\
\text { Coefficients }\end{array}$} & \multirow[b]{2}{*}{$\mathrm{t}$} & \multirow[b]{2}{*}{ Sig. } \\
\hline & & & & \\
\hline \multirow[t]{8}{*}{1} & (Constant) & & 1.124 & .264 \\
\hline & Faktor Intrinsik (Diri Sendiri) & .027 & .222 & .825 \\
\hline & Kualitas Dosen & .042 & .340 & .735 \\
\hline & Metode Perkuliahan & .238 & 2.008 & .048 \\
\hline & Materi Kuliah & .092 & .773 & .442 \\
\hline & Orang Tua & .224 & 2.314 & .023 \\
\hline & Ruang Kuliah / Laboratorium & .243 & 2.320 & .023 \\
\hline & Perpustakaan & .073 & .737 & .463 \\
\hline
\end{tabular}

Arah koefisien regresi variabel diri sendiri (faktor intrinsik) terhadap motivasi belajar mahasiswa adalah sebesar 0,027 dengan arah positif. Hasil pengujian pengaruh faktor intrinsik (diri sendiri) terhadap motivasi belajar mahasiswa tingkat signifikansi sebesar 0,825. Tingkat signifikansi penelitian lebih besar dari tingkat signifikansi sebesar 0,05. Dengan demikian faktor intrinsik (diri sendiri) berpengaruh positif terhadap motivasi belajar mahasiswa namun tidak signifikan.

Arah koefisien regresi variabel kualitas dosen terhadap motivasi belajar mahasiswa adalah sebesar 0,042 dengan arah positif. Hasil pengujian pengaruh kualitas dosen terhadap motivasi belajar mahasiswa tingkat signifikansi sebesar 0,735. Tingkat signifikansi penelitian lebih besar dari tingkat signifikansi sebesar 0,05. Dengan demikian kualitas dosen berpengaruh positif terhadap motivasi belajar mahasiswa namun tidak signifikan.

Arah koefisien regresi variabel metode perkuliahan terhadap motivasi belajar mahasiswa adalah sebesar 0,238 dengan arah positif. Hasil pengujian pengaruh sumber daya manusia terhadap tingkat kepuasan pengguna aplikasi tingkat signifikansi sebesar 0,048. Tingkat signifikansi penelitian lebih kecil dari tingkat signifikansi sebesar 0,05. Dengan demikian metode perkuliahan secara signifikan berpengaruh positif terhadap motivasi belajar mahasiswa.

Arah koefisien regresi variabel materi kuliah terhadap motivasi belajar mahasiswa adalah sebesar 0,092 dengan arah positif. Hasil pengujian pengaruh materi kuliah terhadap motivasi belajar mahasiswa tingkat signifikansi sebesar 0,448. Tingkat signifikansi penelitian lebih besar dari tingkat signifikansi sebesar 0,05. Dengan demikian materi kuliah berpengaruh positif terhadap motivasi belajar mahasiswa namun tidak signifikan.

Arah koefisien regresi variabel orang tua terhadap motivasi belajar mahasiswa adalah sebesar 0,224 dengan arah positif. Hasil pengujian pengaruh orang tua terhadap motivasi belajar mahasiswa tingkat signifikansi 
sebesar 0,023. Tingkat signifikansi penelitian lebih kecil dari tingkat signifikansi sebesar 0,05. Dengan demikian orang tua secara signifikan berpengaruh positif terhadap motivasi belajar mahasiswa.

Arah koefisien regresi variabel ruang kuliah/laboratorium terhadap motivasi belajar mahasiswa adalah sebesar 0,243 dengan arah positif. Hasil pengujian pengaruh ruang kuliah/laboratorium terhadap motivasi belajar mahasiswa tingkat signifikansi sebesar 0,023. Tingkat signifikansi penelitian lebih kecil dari tingkat signifikansi sebesar 0,05. Dengan demikian ruang kuliah/laboratorium secara signifikan berpengaruh positif terhadap motivasi belajar mahasiswa.

Arah koefisien regresi variabel perpustakaan terhadap motivasi belajar mahasiswa adalah sebesar 0,073 dengan arah positif. Hasil pengujian pengaruh perpustakaan terhadap motivasi belajar mahasiswa tingkat signifikansi sebesar 0,463. Tingkat signifikansi penelitian lebih besar dari tingkat signifikansi sebesar 0,05. Dengan demikian perpustakaan berpengaruh positif terhadap motivasi belajar mahasiswa namun tidak signifikan

Dari ketujuh variabel independen yang digunakan yaitu faktor intrinsik, kualitas dosen, metode perkuliahan, materi kuliah, orang tua, ruang kuliah/laboratorium, dan perpustakaan menunjukkan hubungan yang positif terhadap variabel dependen yaitu motivasi belajar mahasiswa. Hal ini menunjukkan kesesuaian dengan penelitian sebelumnya yang dilakukan oleh Martono dan Sulistiowati (2012). Namun beberapa hasil penelitian uji parsial ini tidak menunjukkan signifikan. Hal tersebut kemungkinan disebabkan oleh perbedaan lingkungan penelitian dan perbedaan manajemen pengelola institusi

\section{KESIMPULAN}

Berdasarkan penelitian yang telah dilakukan, maka dapat disimpulkan bahwa :

1. Faktor intrinsik, kualitas dosen, metode perkuliahan, materi kuliah, orang tua, ruangperkulihan/laboratorium, dan perpustakaan secara simultan mempunyai pengaruh yang signifikan terhadap motivasi belajar mahasiswa.

2. Faktor intrinsik (diri sendiri) berpengaruh positif terhadap motivasi belajar mahasiswa namun tidak signifikan.

3. Kualitas dosen berpengaruh positif terhadap motivasi belajar mahasiswa namun tidak signifikan.

4. Metode Perkuliahaan secra signifikan berpengaruh positif terhadap motivasi belajar mahasiswa.

5. Materi Kuliah berpengaruh positif terhadap motivasi belajar mahasiswa namun tidak signifikan.

6. Orang tua secara signifikan berpengaruh positif terhadap motivasi belajar mahasiswa.

7. Ruang kuliah/laboratorium secra signifikan berpengaruh positif terhadap motivasi belajar mahasiswa.

8. Perpustakaan berpengaruh positif terhadap motivasi belajar mahasiswa namun tidak signifikan.

\section{DAFTAR PUSTAKA}

Ghozali, I. (2011). Aplikasi Analisis Multivariate Dengan Program IBM SPSS 19 (Edisi Lima). Semarang : Badan Penerbit Universitas Diponegoro. 
Martono, S., dan Sulistiowati (2012). Analisis Faktor-Faktor yang Mempengaruhi Motivasi Belajar Mahasiswa (Studi Kasus di STIKOM Surabaya), Prosiding Seminar Nasional Sistem \& Teknologi Informasi (SNASTI) 2012. Surabaya : Eprint.

Mediawati, E. (2010). Pengaruh Motivasi Belajar Mahasiswa dan Kompetensi Dosen Terhadap Prestasi Belajar, Jurnal Pendidikan Ekonomi Dinamika Pendidikan, 5, 134-146.

Nurhidayah (2014). Faktor-Faktor yang Mempengaruhi Motivasi Belajar Mahasiswa Program Studi PGSD FKIP Universitas Ahmad Dahlan,
Jurnal Pendidikan Sekolah Dasar, 1, 125-145.

Ramdhan, MY., dan Harsono, LD. (2015). Pengaruh Motivasi Belajar terhdap Prestasi Belajar Mahasiswa Telkom University Program Pendidikan Jarak Jauh Tahun Akademik 2013/2014 (Studi Kasus pada Program Pasca Sarjana), E Proceeding of Management (pp 156-161).

Upoyo, AS. dan Sumawati, M. (2011). Analisis Faktor-Faktor yang Mempengaruhi Motivasi Mahasiswa Profesi Ners Jurusan Keperawatan Unsoed Purwokerto, Jurnal Keperawatan Soedirman, 6, 81-87. 
